\title{
Études/Inuit/Studies
}

\section{Lydia T. Black (1925-2007)}

Volume 31, numéro 1-2, 2007

Tchoukotka

Chukotka

URI : https://id.erudit.org/iderudit/019748ar

DOI : https://doi.org/10.7202/019748ar

Aller au sommaire du numéro

\section{Éditeur(s)}

Association Inuksiutiit Katimajiit Inc.

Centre interuniversitaire d'études et de recherches autochtones (CIÉRA)

\section{ISSN}

0701-1008 (imprimé)

1708-5268 (numérique)

Découvrir la revue

Citer ce document

(2007). Lydia T. Black (1925-2007). Études/Inuit/Studies, 31(1-2), 425-426.

https://doi.org/10.7202/019748ar d'utilisation que vous pouvez consulter en ligne.

https://apropos.erudit.org/fr/usagers/politique-dutilisation/ 


\title{
$\mathbb{I N M E M O R I M A ~}$
}

\author{
Lydia T. Black
}

\section{(1925-2007)}

Dr. Lydia T. Black, an anthropologist whose research restored to Alaskan peoples important features of their history and culture, died on March 12, 2007, in Kodiak, AK. She was 81. Dr. Black's research of the Russian period in Alaska revealed aspects of Native Alaskan culture and history which had been lost or forgotten. Her book Aleut $A r t$ is representative of her career in this respect as it provides a comprehensive look at both the techniques used to create and the symbolic meaning of a variety of pre- and early contact Aleut arts and crafts.

Dr. Black's most recently published book was Russians in Alaska, 1732-1867, a concise and accessible history of the Russian period in Alaska. Anóoshi Lingit Aani Ká / Russians in Tlingit America, The Battles of Sitka, 1802 and 1804, co-edited with Professor Richard L. Dauenhauer and Tlingit poet Nora Marks Dauenhauer, about the Russian-Tlingit battles of 1802 and 1804 at Sitka, Alaska as described by Tlingit oral tradition and contemporary Russian historical documents, will be published later this year. Another work co-authored with Donald W. Clark of the Canadian Museum of Civilization has an anticipated publication date of 2008. She was the author of at least an additional 66 books and articles appearing in publications as diverse as Natural History, Arctic Anthropology and Studies in Soviet Thought and was a contributor to various exhibits and conferences on the Arctic, including the Library of Congress' Meeting of the Frontiers, the New York Museum of Natural History's Jesup Centenary Congress and the Smithsonian Institution's Crossroads of the Continents. She organized the $7^{\text {th }}$ Inuit Studies Conference at University of Alaska Fairbanks in August 1990. She appeared in several documentaries, including Conquest of America (Northwest episode). Regularly appearing as guest lecturer in England, Canada, Russia and Japan as well as other countries, she was one of very few outside scholars to supervise a thesis at England's Oxford University. In 1992, she was elected foreign member to the Center for the Study of Russian America and Russian-American Relations, Institute of History, Russian Academy of Sciences. She served as 
Chairwoman of the international committee for the birthday bicentennial exhibit celebrating Saint Innocent of Alaska in 1996. In 2001, Russia awarded her, among others, the Order of Friendship, honoring her contribution to promoting cross-cultural understanding between Russia and America. A highlight in her retirement was an invitation to speak about Saint Herman of Alaska at Valaam Monastery during its 2003 conference celebrating the completion of renovations there. In addition, she was the recipient of the Alaska Anthropological Association's Lifetime Achievement Award in 2000 and Alaska's Governor's Lifetime Achievement Award for the Humanities in 2005.

Dr. Black was born in Kiev, USSR, on December 16, 1925. Her father was executed by Soviet authorities in 1933, and her mother died of tuberculosis in 1941. While wandering the Ukrainian countryside in search of food during World War II, she was conscripted into forced labor by German forces. At the end of the War, she found herself in Munich, where, with her knowledge of six languages, she worked as a translator for the UNRRA in a displaced children's camp. She married Igor A. Black, a fellow Soviet refugee, in Munich, where they lost their first daughter Olga to measles. In 1950, they emigrated to the United States. (Igor A. Black was a thermodynamics engineer whose work on the Apollo Mission was officially commemorated by NASA.) Upon her husband's death in 1969, she resumed full-time studies, completing her B.A. at Northeastern University, then her M.A. (Brandeis University, 1971) and her Ph.D. (University of Massachusetts-Amherst, 1973), when she accepted her first academic post at Providence College. While teaching at Providence College, she also served as part of the staff of Brown University's Arctic Institute. She moved to Alaska in 1984 in order to be closer to her research interests, accepting a position at University of AlaskaFairbanks, whence she retired in 1998 in order to contribute her skills to St. Herman's Theological Seminary in Kodiak, AK. She was summarily dismissed from her duties at the Seminary by the current Bishop of Alaska, Orthodox Church in America, in 2001, after which she devoted her time to writing and lending her expertise to a variety of individual and collective projects and volunteered as a teacher of Russian history at Saint Innocent's Academy.

Dr. Black is survived by her four daughters, Anna Treiber of Appleton, Wisconsin; Maria McEvoy of Houston, Texas; Elena Black of Dennis, Massachusetts; Zoë Pierson of Kodiak, Alaska, and by six grandchildren and three great-grandchildren.

(Source: Zoë Pierson) 